九州大学学術情報リポジトリ

Kyushu University Institutional Repository

\title{
Phytotoxin Produced by Burkholderia gladioli
}

Furuya, Naruto

Laboratory of Plant Pathology, Faculty of Agriculture, Kyushu University

I iyama, Kazuhiro

Laboratory of Plant Pathology, Faculty of Agriculture, Kyushu University

Shiozaki, Naomi

Laboratory of Plant Pathology, Faculty of Agriculture, Kyushu University

Matsuyama, Nobuaki

Laboratory of Plant Pathology, Faculty of Agriculture, Kyushu University

https://doi.org/10.5109/24188

出版情報 : 九州大学大学院農学研究院紀要. 42 (1/2)，pp.33-37，1997-12. Kyushu University バージョン：

権利関係 : 


\title{
Phytotoxin Produced by Burkholderia gladioli
}

\author{
Naruto Furuya, Kazuhiro Iiyama, Naomi Shiozaki* \\ and Nobuaki Matsuyama
}

\author{
Laboratory of Plant Pathology, Faculty of Agriculture, \\ Kyushu University, Fukuoka 812-81, Japan \\ (Received July 24, 1997 and accepted August 25, 1997)
}

\begin{abstract}
The phytotoxin produced by Burkholderia gladioli was purified and characterized. The ultraviolet and visible absorption spectrum of the phytotoxin exhibited two maxima at $260 \mathrm{~nm}$ and $399 \mathrm{~nm}$ in $80 \%$ aqueous methanol. The molecular weight of this substance was determined as 193 and the molecular formula was decided as $\mathrm{C}_{i} \mathrm{H}_{7} \mathrm{~N}_{5} \mathrm{O}_{2}$ by a high resolution $\mathrm{FAB}$ mass spectrometry. From these results, this substance was identified as toxoflavin.
\end{abstract}

\section{INTRODUCTION}

Bacterial diseases of plants are induced by various disease-principles such as toxin, enzyme, plant hormone and extracellular polysaccharide (EPS) which are produced by phytopathogenic bacteria. However, disease-principles in large part of plant pathogenic bacteria are still unclear. It was found that Burkholderia glumae, which is closely resembled to $B$. gladioli in many bacteriological properties, produced toxoflavin and fervenulin causing inhibition of seedling elongation and chlorosis on rice leaves (Sato $e t$ $a l$, 1989). The authors demonstrated that toxoflavin produced by $B$. glumae is closely associated with its virulence (Iiyama et al., 1994; 1995). These facts led to the speculation that $B$. gladiol $i$ will also excrete toxoflavin. The present study was designed to clarify the disease-principle of $B$. gladioli.

\section{MATERIALS AND METHODS}

\section{Purification and identification of phytotoxin extracted from culture filtrate}

B. gladioli MAFF302424, donated by the Genetic Resources Center, National Institute of Agrobiological Resources, Ministry of Agriculture, Forestry and Fisheries, was used in this study. The bacterium was pre-cultured in a test tube containing $10 \mathrm{ml}$ of potato semi-synthetic broth (PS; $\mathrm{Na}_{2} \mathrm{HPO}_{4} \cdot 12 \mathrm{H}_{2} \mathrm{O} 2.0 \mathrm{~g}, \mathrm{Ca}\left(\mathrm{NO}_{3}\right)_{2} \cdot 4 \mathrm{H}_{2} \mathrm{O} 0.5 \mathrm{~g}$, polypeptone $5.0 \mathrm{~g}$, sucrose $20.0 \mathrm{~g}$ in $1,000 \mathrm{ml}$ decoction of potato $300 \mathrm{~g}$, and the $\mathrm{pH}$ value was adjusted to 7.0 before autoclaving) at $30^{\circ} \mathrm{C}$ for 1 day. Then $5 \mathrm{ml}$ of bacterial suspension was inoculated into $200 \mathrm{ml}$ of PS broth in a $500 \mathrm{ml}$ Sakaguchi-flask and bacteria were grown at $30^{\circ} \mathrm{C}$ for 4 days under shaking conditions. After incubation, the culture filtrate was collected by centrifugation $(4,000 \mathrm{~g}, 10 \mathrm{~min})$. The culture filtrate was concentrated to one tenth of the original volume by evaporation in vacuo at less than $40^{\circ} \mathrm{C}$, and then extracted with chloroform. The extract was developed on a silica-gel

\footnotetext{
* Present address: Kunisaki Agriculture Extension Center, Oita 873-05, Japan
} 
(Wako-gelB-10) TLC plate with dichloromethane-methanol $(9: 1, \mathrm{v} / \mathrm{v})$. The substances were detected under UV $(365 \mathrm{~nm})$ immediately after the developing solvent had reached $10 \mathrm{~cm}$-line from the origin. Every spot detected was scraped and eluted with methanol, and assayed for its phytotoxic activity. Silica-gel powder of the area (Rf 0.4-0.5) exhibiting dark orange-coloration was collected, and eluted with methanol to subject to rechromatography with chloroform-methanol $(9: 1, \mathrm{v} / \mathrm{v})$ solvent system. The bioactive zone was scraped from the silica-gel plate and eluted with methanol. The eluate was concentrated in vacuo and subjected to TLC with ethylacetate-chloroform-acetic acid $(20: 8: 1, \mathrm{v} / \mathrm{v} / \mathrm{v})$. Then, the active zone was scraped from the plate and eluted with distilled water. The eluate with distilled water was shaken with an equal volume of chloroform to remove ash. The chloroform layer was dried with an evaporator followed by nitrogen gas blowing. Purity of the phytotoxin was estimated using a high performance liquid chromatography equipped with Shodex DM614, MS C-18, YMC AQ-312 and Shim-pack CLC-NH $\mathrm{NH}_{2}$ columns and a UV absorbance detector. Samples were injected as $80 \%$ aqueous methanol solution. The phytotoxin was eluted at a flow rate of $1 \mathrm{ml} / \mathrm{min}$ with $80 \%$ methanol Solution and detected at $260 \mathrm{~nm}$. UV spectrum of the phytotoxin was recorded by a Shimadzu UV-2200 spectrophotometer and FAB mass spectrometry spectrum was obtained by a JEOL JMS-D300 spectrometer using a direct inlet system.

\section{Bioassay for toxicity}

The phytotoxic activity was bioassayed by the following method. Rice seeds (cv. "Asominori") were husked, surface disinfected with $70 \%$ ethanol for $1 \mathrm{~min}$ and $3 \%$ hypochlorite solution (Antiformin) for $90 \mathrm{~min}$, and washed in sterile distilled water. Seeds were germinated at $28^{\circ} \mathrm{C}$ for 2 days in the dark. Three pre-germinated seeds were incubated with $2 \mathrm{ml}$ of the test solution passed through membrane filter $(0.22 \mu \mathrm{m})$ at $30^{\circ} \mathrm{C}$ for 14 days under continuous light conditions (34,000-40,000 lux) in test tube. The seeds were similarly treated with sterile distilled water as the check. Toxicity was estimated by measuring the lengths of the sprout and root of the seedling.

\section{RESULTS AND DISCUSSION}

As shown in Fig. 1 and Table 1, remarkable toxic activity was located at the area of Rf $0.4-0.5$, where a dark orange-coloration spot appeared, on the silica-gel TLC plate. The eluate from the corresponding area of a blank chromatogram showed no toxic activity. When the eluate was subjected to the preparative TLC with chloroform-methanol $(9: 1$, $\mathrm{v} / \mathrm{v}$ ), two bioactive spots were detected at Rf 0.14 and 0.34 . The substance at Rf 0.34 was confirmed as an artifact which appeared on the silica-gel plate during TLC. The fraction at Rf 0.14 was subjected to TLC with ethylacetate-chloroform-acetic acid $(20: 8: 1, \mathrm{v} / \mathrm{v} / \mathrm{v})$ and the bioactive substance appeared at Rf 0.12 . This substance was eluted with deionized water, and was transferred to chloroform by shaking with an equal volume of chloroform. The chloroform layer was evaporated and the purity of this sample was estimated by HPLC (Fig. 2). As shown in Fig. 3, the ultraviolet and visible absorption spectrum of the phytotoxin exhibited two maxima at $260 \mathrm{~nm}$ and $399 \mathrm{~nm}$ in $80 \%$ aqueous methanol. The molecular weight of this substance was determined as 193 and the molecular formula was decided as $\mathrm{C}_{7} \mathrm{H}_{7} \mathrm{~N}_{5} \mathrm{O}_{2}$ by a high resolution FAB mass spectrometry 


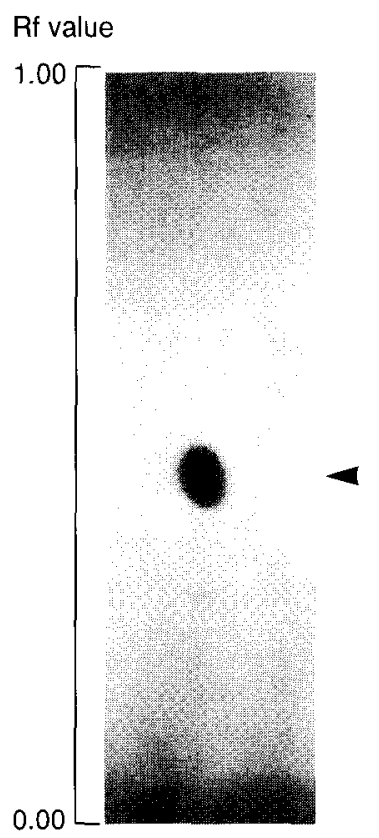

Fig. 1. TLC of the phytotoxin produced by Burkholderia gladioli MAFF302424.

Solvent: dichloromethane-methanol $(9: 1, \mathrm{v} / \mathrm{v})$.

Plate: Silica-gel (Wako-gel B-10).

Arrowhead indicates the spot of the phytotoxin.

Table 1. Growth inhibition of rice seedlings in each fraction of TLC ${ }^{a}$ of the chloroform extract from culture filtrate of Burkholderia gladioli MAFF302424

\begin{tabular}{ccc}
\hline & \multicolumn{2}{c}{ Degree of growth inhibition } \\
\cline { 2 - 3 } & Sprout & Root \\
\hline $0.6-0.8$ & $-b)$ & - \\
$0.5-0.6$ & - & - \\
$0.4-0.5$ & ++++ & +++ \\
$0.3-0.4$ & + & + \\
$0.2-0.3$ & + & + \\
$0.1-0.2$ & - & - \\
\hline
\end{tabular}

a) TLC was conducted with dichloromethane-methanol $(9: 1, v / v)$.

b) The degree of inhibition of rice growth is presented as -: $0 \%,+$ : $0-25 \%,++: 25-50 \%,+++: 50-75 \%,++++: 75-100 \%$. The percent inhibition of rice growth was calculated as follows; \% inhibition = (A -B) $/ \mathrm{A} \times 100$.

$A=$ the length of sprout or root in sterilized distilled water. $B=$ the length of sprout or root in the solution of each fraction at various $R f$ values. 


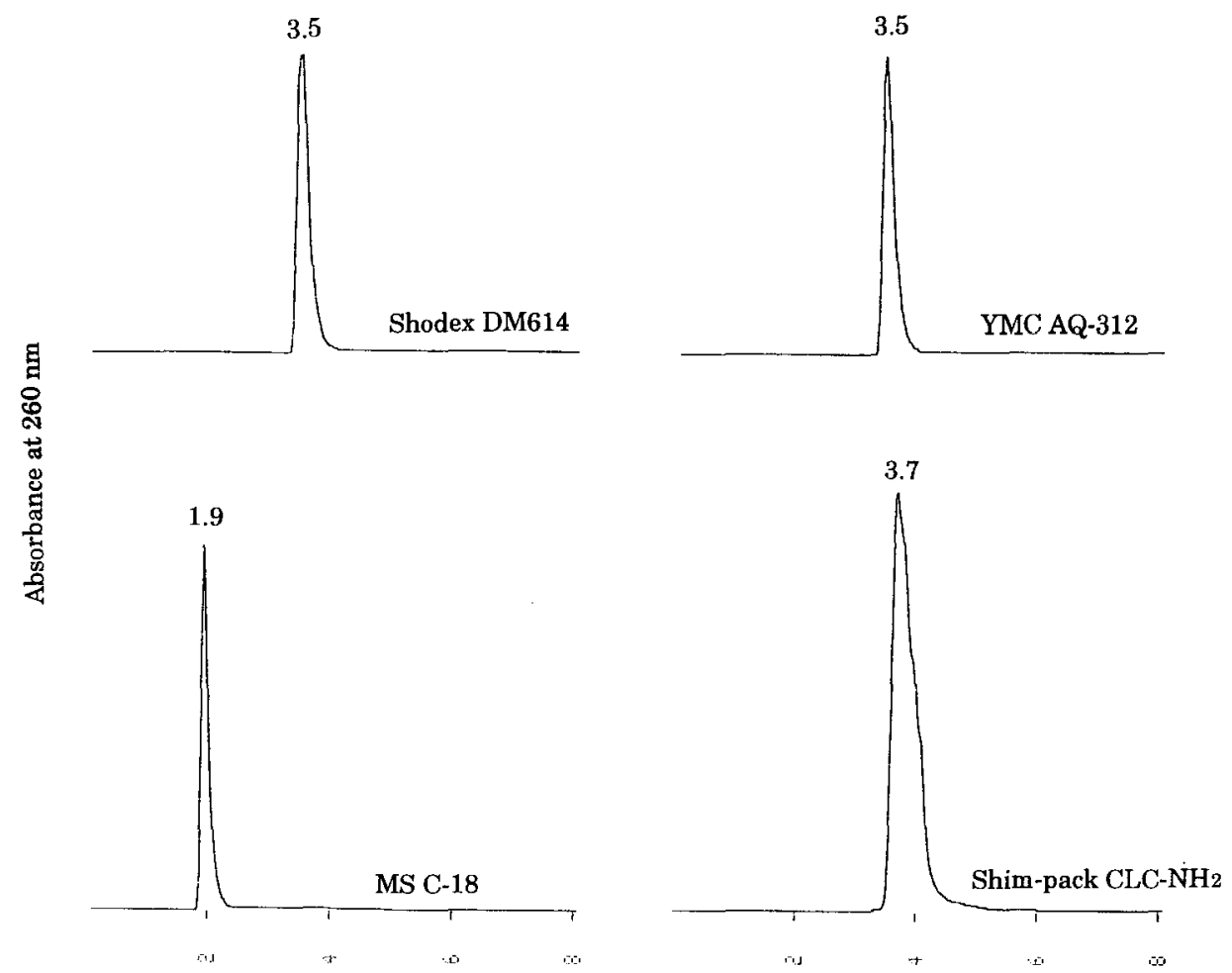

Fig. 2. HPLC chromatograms of the phytotoxin produced by Burkholderia gladioli MAFF302424.

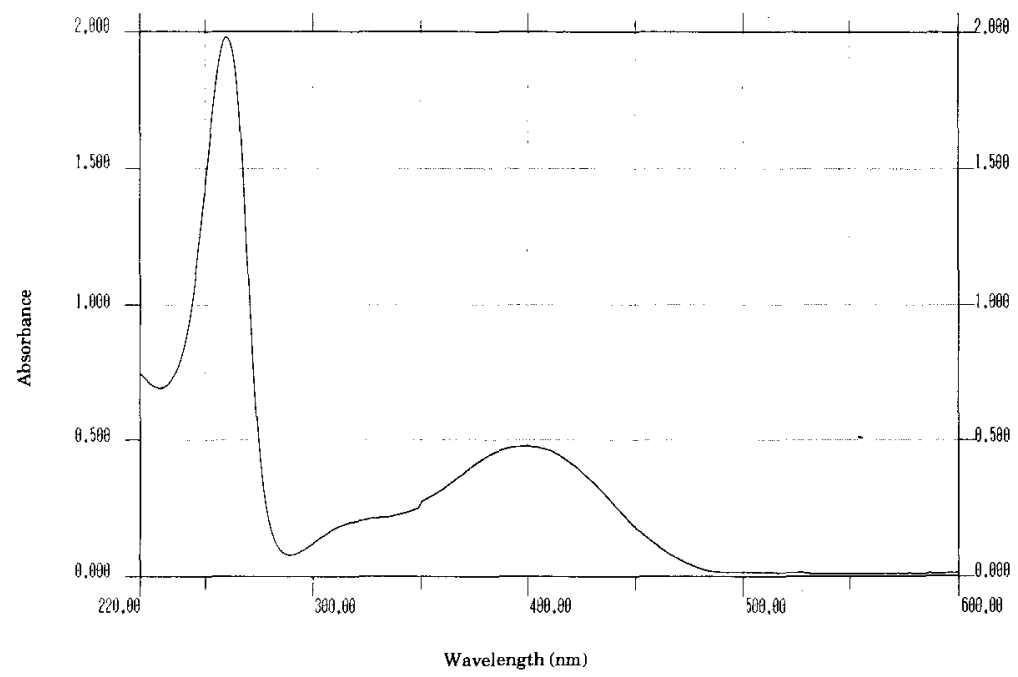

Fig. 3. Visible and ultraviolet absorption spectrum of the phytotoxin produced by Burkholderia gladioli MAFF302424. 
(Fig. 4). From these results, it is clear that B. gladioli also produces toxoflavin as well as $B$. glumae. Further investigation to clarify the role of toxoflavin in pathogenicity of $B$. gladioli is in progress.

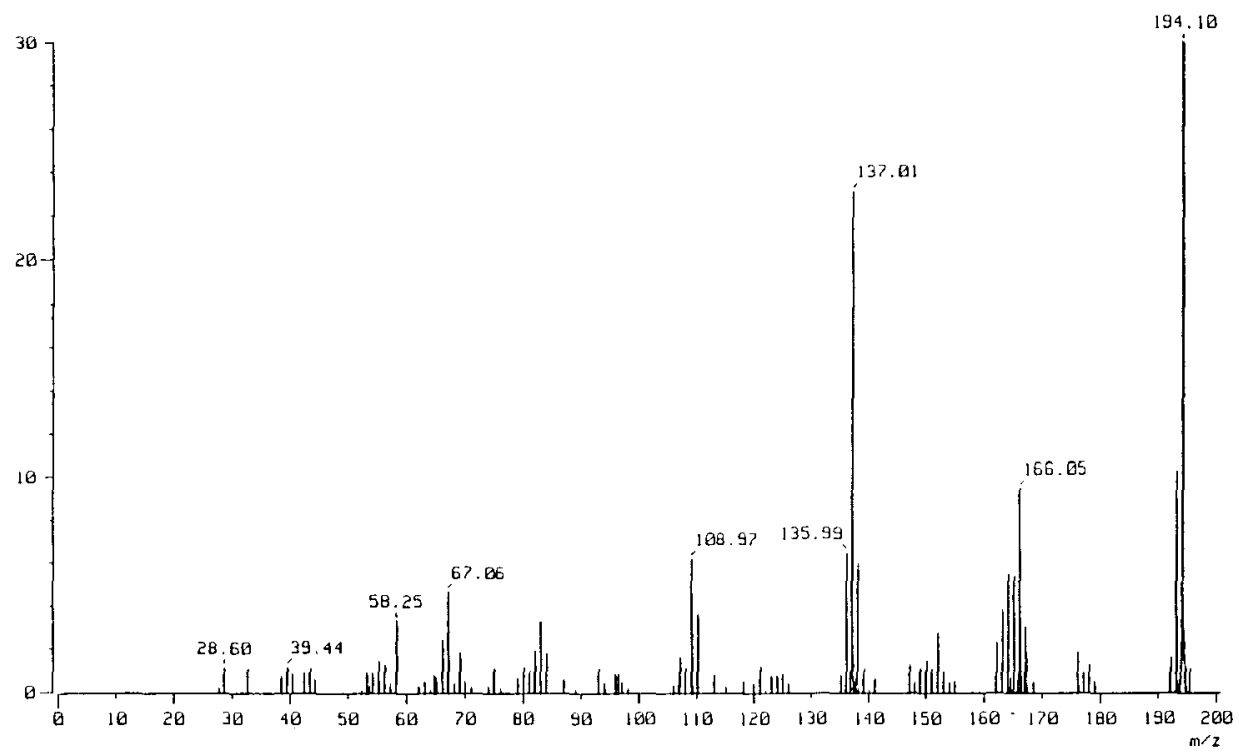

Fig. 4. FAB-MASS spectrum of the phytotoxin produced by Burkholderia gladioli MAFF302424.

\section{REFERENCES}

Sato, Z, Y. Koiso, S. Iwasaki, I. Matsuda and A. Shirata 1989 Toxins produced by Pseudomonas glumae. Ann. Phytopathol. Soc. Jpn., 55: 353-356

Iiyama, K., N. Furuya, K. Hara, N. Nakashima, Y. Takanami and N. Matsuyama 1994 Phytoloxin produced by Pseudomonas glumae Kurita et Tabei, a causal bacterium of the grain and seedling rot of rice. $J$. F'uc. Agr, Kyushu Univ., 38: 175-181

liyama, K., N. Furuya, Y. Takanami and N. Matsuyama 1995 A role of phytotoxin in virulence of Pseudomonas glumae Kurita et Tabei. Ann. Phytopathol. Soc. Jpn., 61: 470-476 